HStud 23 (2009)1, 3-10

DOI: 10.1556/HStud.23.2009.1.1

\title{
FIFTY YEARS IN HAYDN RESEARCH: A PERSONAL ACCOUNT*
}

\author{
LÁSZLÓ SOMFAI \\ Liszt Ferenc Academy of Music, Budapest \\ Hungary
}

\begin{abstract}
The following article offers a short chronicle of the scholarship on Haydn in Hungary since the late 1950 s, identifying some of the major contributions, he raises questions concerning possible further interconnections between the scholarly work of the researcher and the creative work of the performer.
\end{abstract}

Keywords: Haydn, Hungary, manuscript, score, urtext, original instruments, reception theory, folk music

There was little significant scholarly work on Haydn in Hungary until roughly the 1950s. Certainly the time he spent in Hungary in the service of the Esterházy family, the contacts he had with Bratislava (or rather Pozsony or Pressburg, as it was more commonly known at the time), and his journey to Buda to conduct Die Schöpfung awoke some interest and led to some serious scholarly endeavors. Between the two wars Ervin Major, an independent scholar, pursued some work on the Hungarian tunes and dances that influenced Haydn's music, and Endre Csatkai examined local documents of interest in Sopron (or Ödenburg, as it was more commonly known). But for a young professional from the West real partners in Haydn research seemed to be missing. In his search for Haydn's ancestors, Ernst Fritz Schmid could find no professional assistance, and young Jens Peter Larsen, who in the 1930s came to work on primary sources in the Esterházy family archive in Budapest, had to content himself with János Hárich, the archivist, as his sole collaborator. One can only wonder whether at the time they knew that there were Hungarian musicologists who held doctorates from Germany, including Hermann Abert's pupil Bence Szabolcsi and Dénes Bartha, who had studied in Berlin. The best specialized study was perhaps the survey of the baritone works by Béla Csuka, a cellist.

\footnotetext{
* The article is a slightly modified version of the opening address held by László Somfai at the "Haydn 2009: A Bicentenary Conference" in Budapest. 
This changed following World War II. A previously well-guarded private archive including the world's largest Haydn autograph collection, which essentially had remained closed even to scholars, became public in Budapest. Indeed the long isolation of this private collection may very well have been the primary hindrance to earlier scholarly work on Haydn and may furthermore explain the fact that well into the 19th century he was less established as a great composer, and neither an appropriate biography nor a complete edition of his works had been published, because in spite of the limited access granted to Carl Ferdinand Pohl and a few others this central source was not publicly available. The isolation of the Esterházy archive became even more severe when after World War I the new boarder between Austria and Hungary split the Esterházy realm, and all of a sudden it had to be decided which part of the collection should be moved to Hungary and what would remain in Eisenstadt.

The nationalization of the collections of the Esterházy family (partly damaged during the bombing of Budapest) and their distribution among different institutions (including the Museum of Applied Arts, the State Archive, and several departments of the National Library) took place in the late 1940s. The process of distribution was inconsistent from several points of view. "Acta Musicalia" documents were given both to the Theatre History Collection of the National Library and to the State Archive. On the other hand, however, appropriate personnel cared for the documents in their new locations, primarily in the Széchényi National Library. These special collections served as a refuge for well-trained scholars who were politically suspicious and therefore not allowed to work as teachers. The first major study, Mátyás Horányi's work, was based on intensive research of the material in the Theatre History Collection; his well illustrated book of 1959, The Magnificence of Eszterháza, unfortunately came out without appropriate musicological assistance. More problematic was the three-part publication of documents related to Haydn by Arisztid, because Valkó was unable to read the contemporary German texts without making some errors. Hárich, who was released from prison thanks to the revolution in 1956 and relocated to Eisenstadt, reedited documents in H.C. Robbins Landon's series Haydn Yearbook and elsewhere; a scholarly presentation of the Esterházy documents had to wait until a young German, Ulrich Tank appropriately edited them.

The concentration of manpower on the one hand, urged work for the coming Haydn year, 1959, on the other, and in many ways inadequate research conditions (in terms of reference books, communication with collections abroad, availability of microfilms, etc.) equally characterized the beginning research on Haydn in Hungary in those years. According to Jenő Vécsey's introduction to the handsome catalogue volume Haydn Compositions in the National Széchényi Library Budapest (Hungarian edition 1959, German and English 1960), the musicalia arrived in the Music Collection of the library in 1949. Vécsey, the head of the music de- 
partment (primarily a composer, not a musicologist or trained librarian), wisely kept the call numbers given by Hárich. As a personal undertaking motivated by his own interests, Vécsey soon prepared unpublished works for premiere (including L'infedeltà delusa in the Hungarian Radio in 1952). He edited aria volumes, became the editor of a series entitled "Musica Rinata," which brought out first editions from other autograph sources in the Esterhazy material, including works by Michael Haydn (Vécsey's favorite), Werner, Albrechtsberger, Gassmann, and others.

After surveying the voluminous Esterházy material, Vécsey discussed the situation with the rising Hungarian Haydn expert of the time, Dénes Bartha, the first chairman of the newly founded musicology department, a man of practical ideas and energy, and somebody who already had contacts with Haydn scholars abroad. Bartha published several opera volumes for the Joseph Haydn Werke. He alone signed the edition of La canterina (1959, still during Larsen's era in the Joseph Haydn Institut in Köln), but Vécsey assisted him with L'infedeltà delusa (1964) and Le pescatrici (1972). In the case of the latter, Mária Eckhardt helped Bartha, since Vécsey suddenly died in 1966 . Looking back on those early years, these basically one-work-one-source cases were properly prepared for the Joseph Haydn Werke, but for works for which the question of sources was more complex a specialized young team was trained in Köln. This took place during Georg Feder's era, without the participation of any Hungarians. I myself was in fact invited by Dr. Feder to edit La fedeltà premiata. He sent the microfilm of the additional sources, but I was warned not to do anything until he marked Haydn's autograph additions in a copied score for me. Working on the opera material at the time, I was sure of recognizing Haydn's handwriting in ink and pencil and red pencil, so I suggested that he did not need to mark the autograph spots. He was stubborn though, and so I declined the job.

Bartha sought to bring additional manpower to the music collection. In 1958 he offered me a position in Jenő Vécsey's team with the unconcealed purpose of having me work, in addition to my daily responsibilities as a librarian, on the Eszterháza operatic material (parallel to completing my thesis on the string quartets). I confess with some nostalgia that the book Haydn als Opernkapellmeister was completed in two years on the basis of minute examination of the complete manuscript material. Bartha regularly brought new data on the chronicle of the opera performances and took with him for translation what I freshly typed in Hungarian from my part of the book. It was obvious to me that instead of rushing the publication of such an important study we should have taken a bit more time. I should have reorganized and renumbered the anonymous copyists and we should have condensed the descriptions. We also should have foregone the use of italics to emphasize things that were not always of primary importance. However, Bartha very much wanted to bring the edition out as soon as possible. 
On the occasion of the Budapest Haydn conference from September 17-22, 1959 , in front of an audience including distinguished participants (including Larsen, Geiringer, Landon, Fellerer, Mies, E. F. Schmid, Besseler, Lesure, but also Christa Landon, Croll and others), Professor Bartha announced the discovery of unknown Haydn arias inserted in Italian operas. In Larsen's view, this was a minor sensation, as were other Hungarian contributions, including Bence Szabolcsi's seminal study Joseph Haydn und die ungarische Musik, with a visit to the partly restored Esterházy palace in Fertőd/Eszterháza, and additional presents (among others a facsimile edition of the autograph score of the "Farewell" Symphony). For the international community of Haydn research it was a relief that most of the Esterházy had survived intact and would be available for research and for the assembly of a complete critical edition. The occasionally unprofessional steps that we had taken were generously overlooked. For instance our "Farewell" facsimile volume, printed on thick paper with glue-fixed spine binding, a novelty at that time, soon fell apart, and today I am not proud of the text of the commentary. We also accepted the fact that some of the celebrities perhaps abused the hospitality of the library. ${ }^{1}$

Follow-up Hungarian scholarly publications in 1960 included Haydn emlékére, the compendious eighth volume in the series Zenetudományi Tanulmányok (Studies in Musicology), which included studies by Bartha (on the oratorio version of the Seven Last Words), Szabolcsi (Haydn, the musician of the future: the last minuets), Ujfalussy (on a special form in the keyboard sonatas), and Benjamin Rajeczky (on the six late masses). It also included my study on the evolution of string quartet idiom in Haydn's quartets, unfortunately all in a language inaccessible to the broader reading public. Around that time Bärenreiter Verlag asked Bartha to assemble a scholarly (original-language) edition of Haydn's Gesammelte Briefe und Aufzeichnungen on the basis of H. C. R. Landon's 1959 English edition, which came out in 1965 and remains in use, in spite of the considerable amount of data subsequently discovered. As a forerunner, in 1961 Bartha and Révész published a Hungarian volume, Haydn's Life in Documents. Bartha, who participated in the 1961 IMS congress in New York, has been recognized as the ambassador of Hungarian musicology abroad. He was invited to write in periodicals and contribute to Festschriften, so he became the messenger of Haydn research in Hungary. From 1964 to 1981, with short intermissions, he taught in the United States. In a way it was disappointing for us that during this long period his output narrowed to the discussion of themes inspired by folk-music and Liedform problems in the music of Haydn, Beethoven, and Mozart.

As for further projects of the Haydn Year in Hungary, the research of the Haydn pioneers inspired source studies in broader and narrower fields alike. Marianne Pándi's collection of music news from the Preßburger Zeitung and a few similar studies uncovered useful data for the biography; Kornél Bárdos's six 
documentary volumes on the musical life of Transdanubian cities and residences in the 17th-18th centuries (1976-1993) outlined the reception of church music and some other genres by Haydn and his contemporaries. His work has been being continued by Ágnes Sas. From the mid-1960s to the early 1980s I did much of the research on works based primarily on the Esterházy sources. In addition to various shorter studies of different kinds, the picture book Joseph Haydn: Sein Leben in zeitgenössischen Bildern was my next project (first in German 1966, English 1969, Hungarian 1977), with Otto Erich Deutsch's volumes in mind as a model, but combining letters and documents, as well as a chronicle of the works with a rich facsimile selection from the Budapest sources and beyond (this was before the publication of Landon's voluminous five-volume work). Given the mix of sources it was no longer a scholarly work, strictly speaking, but the critical survey of Haydn's portraits nonetheless belongs to the standard iconographic literature. I brought out three of the Haydn autographs of the Széchényi National Library in facsimile in 1972 at EMB with English commentaries: Symphony no. 7 "Le midi" (not a very well-reproduced facsimile, and Sonja Gerlach's documentary studies later threw into question some of my comments) and the two quartets of the "Lobkowitz" set op. 77 (these were used for three decades, not only in scholarly discourse but also by string quartet ensembles, until the Joseph Haydn Werke volume finally appeared in 2003). Because of the language, however, these publications belong to the standard Haydn literature. Even my Hungarian book on Haydn's keyboard sonatas (1979) came out in English (The Keyboard Sonatas of Joseph Haydn: Instruments and Performance Practice, Genres and Styles), although with some sixteen years' delay. I mention my keyboard book because it compelled me to realize that our most ambitious Haydn studies seldom fit into the German or American standards of a regular scholarly book. One should write either for the musicologist or for the performer, but not for both. To do so is a quixotic endeavor, even if details of the notation, ornamentation, style, and concept in context may put the matter in different new light.

I began teaching musicologists in Budapest in 1969, and Haydn became a central vehicle with which to introduce students to studies with original sources, handwritings and watermarks, but also the compositional process, style analysis, and interpretation. In this field I could give them an insight into research standards. From a certain point of view, we exhausted Haydn. This had the negative consequence that few of our students dared to join pursue research on Haydn in the 1970 s- 80 s.

A new chapter began with the work of Katalin Komlós, from the school of Szabolcsi and Bartha. A successful lecturer in Budapest, she studied musicology again, as well as piano, at Cornell University between 1980 and 1983. Her dissertation (written under the supervision of James Webster), her subsequent studies on Haydn (written primarily in English), and the book Fortepianos and Their Mu- 
sic (1995) obviously extend beyond the provenance of Hungarian research on Haydn. Her role in Haydn performance was also significant. Like fortepianist Malcolm Bilson, she introduced new standards in solo and chamber music but also in coaching singers in Haydn songs and part-songs in historically informed performance in this country.

In the meantime the Széchényi Library also changed. In an imposing new building Vécsey's successors had to face increasingly less favorable conditions for research. Microfilms of the Haydn sources were already in Köln anyway, and the music department lost its interest in the study of Haydn. Source studies connected with the forthcoming 18th-century volume of the History of Music in Hungary, which was in the Institute for Musicology of the Hungarian Academy of Sciences, revitalized research in the 1990s, first on Haydn's Kleinmeister contemporaries in Hungary (several volumes of their music appeared in the "Musicalia Danubiana" series published by our host institute) and later on Haydn too. The best representatives of this younger generation included Katalin Szacsvai-Kim, Péter Halász, Zoltán Farkas, and Balázs Mikusi, another doctoral candidate who joined the Cornell University graduate program and is now the new head of the music department of the Széchényi National Library. The research of Mikós Dolinszky constitutes a significant individual scholarly contribution. In 1995 Dolinszky edited Haydn's complete piano sonatas in three volumes in the otherwise not always praised (but for its bargain price often preferred) Könemann Urtext series. It is one of the three reliable complete editions of the Haydn sonatas. In 1997 he edited Haydn's piano pieces in two volumes.

Finally, in Hungary motivated performers traditionally maintain relations with scholars. Bartha was the first advisor of the Tátrai Quartet in Haydn matters. Later significant recordings were released that had been done in consultation with musicologists (one could mention several Haydn operas conducted by Frigyes Sándor and the complete quartet oeuvre played on period instruments). Since 1998 the yearly Haydn in Eszterháza Festival has been an inspiring meeting point of performance oriented scholarship and ambitious interpreters from Hungary and abroad. Naturally a recent European phenomenon has also had some presence in Hungary. Young musicians who chisel their performance practice in the best workshops all over in Europe and do not need assistance come to perform. The charismatic figure here is György Vashegyi, with his choir and period instrument orchestra, who planned large-scale series and conducted fascinating performances in several genres by Haydn.

As a short coda I would add a few personal remarks on Haydn studies outside Hungary. Today I very much miss the sensation of large-scale scholarly gatherings, such as the one in which I had the privilege of participating in 1975 at the famous International Haydn Conference in Washington, D.C., organized by Jens Peter Larsen and young James Webster. Scholars from a variety of fields and sev- 
eral countries were present, as were performers and music critics, and in general round table discussions were held instead of presentations. I also miss the standards, openness, and inspiration of exclusive meetings with the neighboring camps, such as the colloquium on the string quartet autographs of Haydn, Mozart, and Beethoven in the Isham Library at Harvard University in 1979, where Haydn specialists for the first time felt that Haydn studies were perhaps no more the last among the Viennese Classics in quality and scope. At the same time I am disappointed that even today serious research on Haydn is undertaken in only a handful of countries (in contrast to the work on Mozart, for instance). The dominance of German and US musicology in characteristically different research areas (perhaps with the exception of James Webster, who is equally influential in both) cannot be questioned. Recently Great Britain has become the third country to play a significant role in publication. But several great European countries with extensive university networks produced very little research on Haydn.

The Joseph Haydn Werke edition, prepared for the bicentenary, is nearing completion. One could perhaps criticize the timing of the appearance of the individual volumes. It was extremely favorable for some work groups, yet confusing for other crucial genres (on the one hand one might think of the sudden discovery of Haydn's keyboard sonatas as early as the late 1960s, by the way as a result of the competing Wiener Urtext and JHW volumes; on the other hand string quartets had to wait until this year for the last important volume or conductors had to produce ambitious symphony recordings partly without the JHW text). Thanks to the professionalism of the Joseph Haydn Institut, due primarily to Dr. Feder, it is a perfect "library edition", and I am convinced that the JHW series is a considerably more durable intellectual product than, e.g., the Neue Mozart Ausgabe. But the omnipotent role of critical editions, which began in the 1950 s, is rightly questioned today, in part because in making an impeccable text of a scholarly edition a certain kind of self-defensive attitude on the part of the editors has priority over the interest of the intelligent user. One could hazard the contention that leading musicologists and conscientious editors, especially in continental Europe, may occasionally be mediocre musicians with old-fashioned tastes. As a result, among the best musicians the respect for scholarly editions sometimes varies. Some are happy to re-study their repertoire, others only trust an original source, while others are content with any contemporary source. I would argue for the use of the scholarly edition as a starting point, but only with the proviso that we must remain open and willing to revise our conclusions.

With the completion of the critical edition, Joseph Haydn's music may very well undergo reevaluation. Younger scholars will probably put aside the basic books and studies written by our generation. In the next decade performers may play an inspiring role in assigning important topics for main-stream scholarship on Haydn. One can hope that, with the creation of the canonized text of the whole 
oeuvre, musicology as a discipline will devote more energy to complex research on questions of performance practice, including the study of the basics of Haydn's notation, the proper reading in its genre-oriented variant forms, and chronological changes, including the possibly different meanings of common signs and the yet unanswered questions of the perspicuous performers of his music.

\section{Note}

1 H. C. R. Landon quickly published Haydn's newly discovered inserted arias. He accepted my study 'Zur Echtheitsfrage des Haydn'schen »Op. 3«' for the Haydn Yearbook, however, first he looked into the matter and thanks to a lucky find by Alan Tyson, he printed the probable answer to my query first (Tyson, Landon (1964) 'Who composed Haydn's Op. 3?', Musical Times, CV/1457, July, 506-507) and two years later brought out my study (Haydn Yearbook 1965, Wien: Universal Edition, 1966, 153-165). 